secretions, symptom severity, symptom duration, functional status, and similar clinically important markers. It remains to be seen if the diagnosis sinusitis, however defined, is that important for determining treatment and prognosis.

We thank the general practitioners of Almere-Haven group for their collaboration. This study was supported by a grant from the Netherlands Organisation for Scientific Research (NWO), grant number HAG 715111, and a grant from the Praeventiefonds, grant number 28-1415.

\footnotetext{
1 Lamberts $\mathrm{H}$, Brouwer $\mathrm{HJ}$, Mohrs J. Reason for encounter-episode- and processoriented standard output from the transition project. Amsterdam: Department of onented standard output from the transition project. Amsterdam: Depart

2 Lamberts H. In het huis van de huisarts; verslag van het Transitieproject. Lamberts H. In het huis van
Lelystad: Meditekst, 1991 .

Lelystad: Meditekst, 1991.
Van den Hoogen HJM, Huygen FJA, Schellekens JWG, Straat JM, Van der Velden HGM. Morbidity figures from general practice 1978-1982. Nijmegen Nijmeegs Universitair Huisartsen Instituut, 1985.

4 Royal College of General Practitioners, Office of Population Censuses, Department of Health and Social Security. Morbidity statistics from general practice 1981-82. London: HMSO, 1986

5 Axelsson A, Chidekel N. Symptomatology and bacteriology correlated to radiological findings in acute maxillary sinusitis. Acta Otolaryngol 1972;74 $118-22$.

6 Axelsson A, Runze U. Symptoms and signs of acute maxillary sinusitis. Otorhinolaryngology 1976;38:298-308.

7 Axelsson A, Runze U. Comparison of subjective and radiological findings during the course of acute maxillary sinusitis. Ann Otol Rhinol Laryngol 1983;92:75-8.

8 Berg O, Bergstedt $\mathbf{H}$, Carenfelt C, Lind MG, Perols O. Discrimination of purulent from nonpurulent maxillary sinusitis. Ann Otol Rhinol Laryngol 1981;90:272-5.
}

9 Berg O, Carenfelt C. Analysis of symptoms and clinical signs in the maxillary sinus empyema. Acta Otolaryngol (Stockh) 1988;105:343-9.

10 Revonta $M$. Ultrasound in the diagnosis of maxillary and frontal sinusitis. Acta Otolaryngol 1980;suppl 370:1-54.

11 Jannert M, Andreasson L, Holmer NG, Lörinc P. Ultrasonic examination of the paranasal sinuses. Acta Otolaryngol 1982;suppl 389:29-52.
the

12 Bauer WJ, Bockmeyer M. Endoskopisch kontrollierte Ultraschalldiagnostik der Kieferhohlen. Laryngology Rhinology Otology 1983;62:443-5.

13 Otten FWA, Bouwhuis-Hoogerwerf ML, Grote JJ. Echografie als onderzoekmethode van de sinus maxillaris. Ned TijdschrGeneeskd 1984;128: $1941-4$

14 Vuorinen P, Kauppila A, Pulkkinen K. Comparison of results of röntgen examination and puncture and irrigation of the maxillary sinuses. $f$ Laryngol 1962;76:359-64.

15 McNeill RA. Comparison of the findings on transillumination, $x$-ray and lavage of the maxillary sinus. $\mathcal{F}$ Laryngol Otol 1963;72:1009-13.

16 Illum P, Jeppesen F, Langebaek E. X-ray examination and sinoscopy in maxillary sinus disease. Acta Otolaryngol 1972;74:287-92.

17 Otten FWA, Engberts GER, Grote JJ. Ultrasonography as a method of examination for the frontal sinus. Clin Otolaryngol 1990;16:285-7.

18 Suompää J, Revonta $M$. Diagnosis of frontal sinusitis: one-dimensional ultrasonography versus radiography. F Laryngol Otol 1989;103:765-7.

19 Davidson TM, Brahme FJ, Gallagher ME. Radiographic evaluation for nasal dysfunction: computed tomography versus plain films. Head Neck 1989;11: 405-9.

20 Lloyd GAS, Lund VJ, Scadding GK. CT of the paranasal sinuses and functional endoscopic surgery: a critical analysis of 100 symptomatic functional endoscopic surgery: a critical

21 Albert A, Harris EK. Multivariate interpretation of clinical labnratory data. New York: Marcel Dekker, 1987.

22 Vainio-Matilla J. Correlations of nasal symptoms and signs in a random sampling study. Acta Otolaryngol 1974;suppl 318:1-48.

23 Savolainen S. Allergy in patients with acute maxillary sinusitis. Allergy 1989;44:116-22.

24 Ylikoski J, Savolainen S, Jousimies-Somer $\mathrm{H}$. The bacteriology of acute maxillary sinusitis. Otorhinolaryngology 1989;51:175-81.

(Accepted 22 fuly 1992)
Department of

ology and

Population Sciences,

London School of Hygiene

and Tropical Medicine,

London WC1E 7HT

D A Leon, lecturer in

epidemiology

Swedish Institute for Social Research, S-106 09

Stockholm, Sweden

D Vågerö, reader in medical sociology

Medical Birth Registry, National Board of Health and Social Welfare S-106 30 Stockholm, Sweden

P Otterblad Olausson, section head

Correspondence to:

Dr Leon.

BMF 1992;305:687-91

\title{
Social class differences in infant mortality in Sweden: comparison with England and Wales
}

\author{
D A Leon, D Vågerö, P Otterblad Olausson
}

\section{Abstract}

Objectives - To investigate social class differences in infant mortality in Sweden in the mid-1980s and to compare their magnitude with that of those found in England and Wales.

Design-Analysis of risk of infant death by social class in aggregated routine data for the mid-1980s, which included the linkage of Swedish births to the 1985 census.

Setting-Sweden and England and Wales.

Subjects - All live births in Sweden (1985-6) and England and Wales (1983-5) and corresponding infant deaths were analysed. The Swedish data were coded to the British registrar general's social class schema.

Main outcome measures-Risk of death in the neonatal and postneonatal period.

Results-Taking the non-manual classes as the reference group, in the neonatal period in Sweden the manual social classes had a relative risk for mortality of 1.20 (95\% confidence interval 1.02 to 1.43) and those not classified into a social class a relative risk of $1.08(0.88$ to 1.33$)$. In the postneonatal period the equivalent relative risks were $1.38(1.08$ to 1.77) for manual classes and $2.14(1.65$ to 2.79$)$ for the residual; these are similar to those for England and Wales $(1.43$ (1.36 to 1.51$)$ for manual classes, $2.62(2.45$ to 2.81$)$ for the residual)

Conclusions - The existence of an equitable health care system and a strong social welfare policy in Sweden has not eliminated inequalities in postneonatal mortality. Furthermore, the very low risk of infant death in the Swedish non-manual group (4.8/ 1000 live births) represents a target towards which public health interventions should aim. If this rate prevailed in England and Wales, $63 \%$ of postneonatal deaths would be avoided.

\section{Introduction}

Sweden's record on infant mortality is remarkable. Between 1920 and 1981 it had the lowest reported infant mortality of any country in the world. Between 1982 and 1986 it moved to second or third place behind either Japan or Finland.' This pre-eminent position has been maintained in the face of a continuous decline in infant mortality throughout the developed world, including Sweden itself. ${ }^{2-5}$

Sweden is often regarded as setting a standard to which other countries aspire, as shown by the many studies that have compared rates and trends in other countries with those in Sweden. ${ }^{5-9}$. In addition, the Swedish welfare and health care systems have been scrutinised to glean ideas as to how other countries might reduce infant mortality. ${ }^{10}$

There has been less awareness internationally of the existence of socioeconomic differences in infant mortality within Sweden. Regional differences in infant mortality were large in the early parts of this century but have since declined substantially. ${ }^{24}$ Socioeconomic differences, unlike regional ones, have not been routinely monitored. The paucity of information on this subject has encouraged the assumption that, today, socioeconomic differences in infant mortality do not exist in Sweden or other Scandinavian countries. ${ }^{112}$

A recent, widely read review of inequalities in health stated that "the conclusion, expressed by many [is] that social inequalities in health in early life are negligible in Sweden, at least in those areas where information is available."13

Several studies of socioeconomic differences in birth outcome in Sweden have been published ${ }^{14-18}$ but, as discussed below, they have several limitations. Our study focuses on inequalities in infant mortality in Sweden, placing them in the context of Britain, a 
country with well recognised socioeconomic differences in infant mortality.

\section{Methods}

To compare socioeconomic differences in Sweden with those in England and Wales the Swedish data were coded to the British registrar general's social class schema. As discussed later this creates some problems, but it is clearly preferable to using a different classification for each country as has mostly been the case in other comparative studies. ${ }^{1319}$

\section{SWEDEN}

All live births registered in Sweden in 1985 and 1986 and all deaths occurring to these infants within one year of their birth as collated by the Swedish medical birth register were analysed. This register routinely links information collected at antenatal visits, delivery, and death and is regarded as being virtually complete. ${ }^{20}$ Selected information on individuals and households from the 1985 Swedish census relating to mothers who gave birth in the period 1985-6 was linked to routine information from the medical birth register.

Births were allocated to a social class on the basis of census information on the occupation and employment status of the mother's cohabitant, irrespective of marital status. This exercise drew on the experience of the Swedish Institute for Social Research, which conducted earlier comparative studies of social class differences in mortality and morbidity in Sweden and Britain. ${ }^{21}{ }^{22}$ As described elsewhere, ${ }^{23}$ each combination of occupation and employment status in the data set was reviewed and assigned to a social class using the 1980 registrar general's classification of occupations..$^{24}$ In addition to social classes $I$ to $V$, two further categories were defined. An "other" category comprised births to women whose cohabitant at census was a student, unemployed, or in the armed services; did not state an occupation; or whose occupation was inadequately described. Births to women who did not have a cohabitant at census, or for whom the cohabitant's details could not be linked, were assigned to a separate category.

\section{ENGLAND AND WALES}

All live births and infant deaths registered in England and Wales in the years 1983-5 were analysed. Counts of these births and deaths by social class were obtained from published and unpublished tabulations produced routinely by the Office of Population Censuses and Surveys.

Social class was routinely coded for $10 \%$ of all live births according to the 1980 classification of occupations, ${ }^{24}$ based on parental occupation given at birth registration. All infant deaths (under 1 year) occurring in $1983-5$ were included. Only $10 \%$ of the deaths could be allocated to a class from the birth registration, so each death was allocated to a social class

TABLE I - Live births by social class and country

\begin{tabular}{|c|c|c|c|c|c|c|}
\hline \multirow{4}{*}{$\begin{array}{l}\text { Social class } \\
\text { I } \\
\text { II } \\
\text { III Non-manual }\end{array}$} & \multicolumn{3}{|c|}{ England and Wales } & \multicolumn{3}{|c|}{ Sweden } \\
\hline & \multirow{2}{*}{$\begin{array}{c}\text { No of live births } \\
122676\end{array}$} & \multicolumn{2}{|c|}{ Percentage } & \multirow{2}{*}{$\frac{\text { No of live births }}{11161}$} & \multicolumn{2}{|c|}{ Percentage } \\
\hline & & 6.4 & & & $5 \cdot 7$ & \\
\hline & $\begin{array}{l}374697 \\
184241\end{array}$ & $\begin{array}{r}19 \cdot 5 \\
9.6\end{array}$ & $35 \cdot 5$ & 39472 & $\begin{array}{r}20 \cdot 0 \\
8.1\end{array}$ & $33 \cdot 8$ \\
\hline III Manual & 647317 & 33.7 & & 59269 & $30 \cdot 2$ & \\
\hline IV & 268261 & 14.0 & $54 \cdot 1$ & 22911 . & $11 \cdot 7$ & $44 \cdot 8$ \\
\hline $\mathrm{V}$ & 123473 & 6.4 & & 5645 & 2.9 & \\
\hline $\begin{array}{l}\text { Other } \\
\text { "Sole" }\end{array}$ & $\begin{array}{r}76486 \\
123468\end{array}$ & $\begin{array}{l}4 \cdot 0 \\
6 \cdot 4\end{array}$ & $10 \cdot 1$ & $\begin{array}{l}18405 \\
23761\end{array}$ & $\begin{array}{r}9 \cdot 4 \\
12 \cdot 1\end{array}$ & $21 \cdot 5$ \\
\hline Total & 1920619 & 100 & 100 & 196553 & 100 & 100 \\
\hline
\end{tabular}

*In England and Wales this category comprised births registered by the mother only. In Sweden it comprised principally births to mothers for whom no cohabitant could be identified. according to occupation stated on the death certificate..$^{25}$

For this analysis births were categorised by social class of father only for those registered within marriage or registered outside marriage by the father and mother jointly. An "other" category was defined for births registered within marriage or jointly registered outside of marriage when on the birth registration the father was a student, unemployed, or in the armed services; did not state an occupation; or his occupation was inadequately described. Births registered by the mother alone (sole registrations) were allocated to a separate category as the father's occupational details were not available.

\section{INFANT MORTALITY}

For both Sweden and England and Wales, infant mortality was divided into neonatal mortality and postneonatal mortality. Neonatal mortality relates to deaths occurring within the first 28 days of life, postneonatal mortality to subsequent deaths within the first year. The risk of neonatal and postneonatal death was calculated by dividing the numbers of deaths by the total number of live births in corresponding social class categories.

The effects of social class on mortality within each country are expressed as a series of ratios in which the risk in each category is related to that seen in the nonmanual classes. The $95 \%$ confidence intervals were calculated on the assumption that the observed number of deaths were drawn from a Poisson distribution. ${ }^{26}$ The public health significance of the differences in risk was examined by calculating the proportion of observed deaths that would have been avoided in each country under three assumptions: firstly, that the risks within each country were reduced to those of the non-manual group in that country; secondly, that the risks in England and Wales were reduced to those observed in Sweden as a whole; and, thirdly, that the risks in each country were reduced to the level of the Swedish non-manual group. Confidence intervals for the proportions of avoidable deaths were calculated using estimates of the variance of the logarithm of the avoidable proportion. ${ }^{27}$

\section{Results}

Table I shows the distributions of live births by social class in Sweden and in England and Wales. The proportion of live births within the non-manual classes (I-III non-manual) was very similar. The residual categories of "other" and "sole registration or no cohabitant" made up a fifth of the Swedish live births but only a tenth of those in England and Wales.

Mortality by social class and country, and the corresponding risks, are shown in tables II and III for the neonatal and postneonatal periods. Overall, in the neonatal period the risks for England and Wales were 1.5 times those in Sweden, while in the postneonatal period they were 1.9 times greater. Within each social class category the risks in England and Wales were greater than those in Sweden. In England and Wales the neonatal and postneonatal mortality risks rise smoothly from class I to class V. For Sweden there is no such regular pattern.

To provide more stability in estimates, tables II and III also show risks for the non-manual and manual class aggregates. There is an additional reason for aggregating the data in this way. In the Swedish data there was sometimes doubt as to which of the two adjacent classes at either end of the schema (I or II, IV or V) an individual should be allocated to; the aggregates minimise misclassification. ${ }^{23}$

The risk ratios for the manual, non-manual, and residual categories are also shown in tables II and III. In the neonatal period the relative risks for England 


\begin{tabular}{|c|c|c|c|c|c|c|c|c|}
\hline \multirow{3}{*}{$\frac{\text { Social class }}{\text { I }}$} & \multicolumn{4}{|c|}{ England and Wales } & \multicolumn{4}{|c|}{ Sweden } \\
\hline & \multirow{2}{*}{ No of deaths } & \multicolumn{2}{|c|}{$\begin{array}{l}\text { Risk } / 100000 \\
\text { live births }\end{array}$} & \multirow{3}{*}{$\begin{array}{c}\begin{array}{c}\text { Relative risk } \\
\text { (95\% confidence interval) }\end{array} \\
1.00\end{array}$} & \multirow{3}{*}{$\begin{array}{c}\text { No of deaths } \\
43 \\
131 \\
47\end{array}$} & \multicolumn{2}{|c|}{$\begin{array}{l}\text { Risk } / 100000 \\
\text { live births }\end{array}$} & \multirow{3}{*}{$\begin{array}{c}\begin{array}{c}\text { Relative risk } \\
(95 \% \text { confidence interval })\end{array} \\
1.00\end{array}$} \\
\hline & & 432 & & & & 385 & & \\
\hline II & $\begin{array}{r}1700 \\
892\end{array}$ & $\begin{array}{l}454 \\
484\end{array}$ & 458 & & & $\begin{array}{l}332 \\
295\end{array}$ & 332 & \\
\hline III Manual & 3477 & $\begin{array}{l}404 \\
537\end{array}$ & & & 245 & 413 & & \\
\hline IV & 1748 & 652 & 582 & $1.27(1.22$ to 1.33$)$ & 86 & 375 & 400 & $1.20(1.02$ to 1.43$)$ \\
\hline $\mathrm{v}$ & 819 & 663 & & & 20 & 354 & & \\
\hline $\begin{array}{l}\text { Other } \\
\text { "Sole" }\end{array}$ & $\begin{array}{l}582 \\
872\end{array}$ & $\begin{array}{l}761 \\
706\end{array}$ & 727 & $1.59(1.49$ to 1.69$)$ & $\begin{array}{l}65 \\
87\end{array}$ & $\begin{array}{l}353 \\
366\end{array}$ & 360 & $1.08(0.88$ to 1.33$)$ \\
\hline Total & 10620 & 553 & & & 724 & 368 & & \\
\hline
\end{tabular}

*In England and Wales this category comprised births registered by the mother only. In Sweden it comprised principally births to mothers for whom no cohabitant could be identified.

TABLE III - Postneonatal mortality risks by social class and country

\begin{tabular}{|c|c|c|c|c|c|c|c|c|}
\hline \multirow{3}{*}{$\frac{\text { Social class }}{\text { I }}$} & \multicolumn{4}{|c|}{ England and Wales } & \multicolumn{4}{|c|}{ Sweden } \\
\hline & \multirow{2}{*}{$\frac{\text { No of deaths }}{296}$} & \multicolumn{2}{|c|}{$\begin{array}{l}\text { Risk/100000 } \\
\text { live births }\end{array}$} & \multirow[t]{2}{*}{$\begin{array}{c}\text { Relative risk } \\
(95 \% \text { confidence interval })\end{array}$} & \multirow{2}{*}{$\begin{array}{c}\text { No of deaths } \\
17\end{array}$} & \multicolumn{2}{|c|}{$\begin{array}{l}\text { Risk/100000 } \\
\text { live births }\end{array}$} & \multirow[t]{2}{*}{$\begin{array}{c}\text { Relative risk } \\
\text { (95\% confidence interval) }\end{array}$} \\
\hline & & 241 & & & & 152 & & \\
\hline II & 1080 & 288 & 282 & $1 \cdot 00$ & 66 & 167 & 146 & 1.00 \\
\hline III Non-manual & 544 & 295 & & & 14 & 88 & & \\
\hline $\begin{array}{l}\text { III Manual } \\
\text { IV } \\
\text { V }\end{array}$ & $\begin{array}{r}2282 \\
1192 \\
721\end{array}$ & $\begin{array}{l}353 \\
444 \\
584\end{array}$ & 404 & $1.43(1.36$ to 1.51$)$ & $\begin{array}{r}116 \\
51 \\
9\end{array}$ & $\begin{array}{l}196 \\
223 \\
159\end{array}$ & 200 & $1.38(1.08$ to 1.77$)$ \\
\hline $\begin{array}{l}\text { Other } \\
\text { "Sole"* }\end{array}$ & $\begin{array}{l}588 \\
891\end{array}$ & $\begin{array}{l}769 \\
722\end{array}$ & 740 & $2.62(2.45$ to 2.81$)$ & $\begin{array}{l}55 \\
77\end{array}$ & $\begin{array}{l}299 \\
324\end{array}$ & 313 & $2 \cdot 14(1.65$ to 2.79$)$ \\
\hline Total & 7594 & 395 & & & 405 & 206 & & \\
\hline
\end{tabular}

*In England and Wales this category comprised births registered by the mother only. In Sweden it comprised principally births to mothers for whom no cohabitant could be identified.

TABLE IV-Percentage of observed deaths ( $95 \%$ confidence interval) that would be avoided if mortality in each country was reduced

\begin{tabular}{lccccc}
\hline & \multicolumn{2}{c}{ Neonatal mortality } & & \multicolumn{2}{c}{ Postneonatal mortality } \\
\cline { 2 - 3 } Hypothetical level of reduced mortality & England and Wales & Sweden & & England and Wales & Sweden \\
\hline Non-manual classes within country & $17(16-18)$ & $10(4-26)$ & & $29(26-31)$ & $29(20-42)$ \\
Total Swedish population & $33(27-41)$ & & $48(43-53)$ & $29(20-42)$ \\
Swedish non-manual classes & $40(33-49)$ & $10(4-26)$ & & $63(56-71)$ & 29 \\
\hline
\end{tabular}

and Wales are somewhat larger than in Sweden. The increase in risk from non-manual through manual to residual categories seen in the neonatal period in England and Wales is not found in Sweden. However, relative risks for the postneonatal period are much more similar in the two countries and show a systematic pattern of increase.

Relative to the Swedish non-manual category, the neonatal risks in England and Wales are 1.38 (95\% confidence interval 1.20 to 1.58 ) for the non-manual, $1.75(1.53$ to 2.00$)$ for the manual, and $2.19(1.90$ to 2.52 ) for the residual categories. In the postneonatal period the corresponding relative risks are $1.93(1.58$ to $2 \cdot 37), 2 \cdot 77$ ( $2 \cdot 26$ to 3.38$)$, and $5.07(4 \cdot 13$ to 6.22$)$.

Table IV shows the percentage of neonatal and postneonatal deaths that would have been avoided in each country under various assumptions. If both countries had risks equal to that of the Swedish nonmanual group, then the percentage reductions in mortality shown in table IV, when applied to observed mortality in 1988 (the latest year for which figures are jointly available), would have resulted in the avoidance of 1350 neonatal and 1760 postneonatal deaths in England and Wales, and 40 neonatal and 70 postneonatal deaths in Sweden.

\section{Discussion}

The existence of socioeconomic differences in infant mortality in Sweden in the early decades of this century was shown by Rietz in an analysis of mortality in
Stockholm by family income. ${ }^{28}$ Twofold differences were observed between the highest and lowest of four income categories for deaths in the first month of life, while much greater differences were seen in the remaining period up to one year. The data presented here suggest that differences of this magnitude no longer exist in Sweden. Nevertheless, our analyses indicate that in the mid-1980s social class differences in postneonatal mortality in Sweden were still fairly pronounced and were of roughly the same magnitude as seen in England and Wales. Social class differences in neonatal mortality in Sweden are small and are even less than in England and Wales.

These findings are consistent with the results of the other studies published over the past decade that have attempted to quantify socioeconomic differences in adverse birth outcome in Sweden, ${ }^{1418}$ all of which used data from the Swedish Medical Birth Register.$^{20}$ In the period 1976-7 the perinatal mortality rate for babies born to women classified as most disadvantaged was 1.2 times that for babies born to those least disadvantaged. ${ }^{14}$ For the neonatal period slightly larger relative risk of around 1.3 were found. ${ }^{18}$ None of these rates was significantly different from 1.0 at the $5 \%$ level.

Ericson et al reported a postneonatal relative risk of $1 \cdot 3(0 \cdot 8$ to $2 \cdot 2)$ between the most and least advantaged socioeconomic groups. ${ }^{18}$ These groups contained only $18 \%$ of live births (most advantaged $11 \%$, least advantaged $7 \%$ ), and had been constructed to define two groups that differed as much as possible in terms of maternal socioeconomic characteristics such as Swedish citizenship, occupation, cohabitation status, housing conditions, and ownership of place of residence. ${ }^{17}$ It is therefore surprising that the differentials in infant mortality seen using this classification are not more substantial than those seen in our analysis between the non-manual and manual classes (relative risk $=1 \cdot 38$ ), which covered $90 \%$ of live births (non-manual $36 \%$, manual 54\%).

Chance may explain this apparent anomaly; the 95\% confidence interval for the postneonatal relative risk 
given by Ericson et al suggests that the true risk could be as high as $2 \cdot 2$. However, social class of cohabitant may be a more powerful tool for differentiating between groups with different levels of infant mortality than the socioeconomic classification of maternal characteristics used by Ericson $e t$ al. This is an issue of considerable sociological interest, touching on the question of how to assign social class to families. We are pursuing this further by investigating the mutually adjusted effects of maternal and paternal socioeconomic characteristics on infant mortality.

A general problem that affects all international comparisons of socioeconomic differences in health ${ }^{2930}$ is the degree to which the classifications used are truly comparable. Our approach has been to use the same classification for both countries. We recognise that the registrar general's social classes were devised to reflect the general standing in Britain of people according to their occupation. Although the Swedish data do not show the same smooth gradient over social classes as seen in England and Wales, there is no reason to believe that this invalidates the simple comparison of manual with non-manual that we base our conclusions on. For more detailed comparisons we would want a classification of social class based more on sociological factors than is the registrar general's schema, the theoretical underpinnings of which are questionable. ${ }^{31}$

A further potential problem in comparing the effects of social class in Sweden with those in England and Wales arises because the distribution of live births among the social classes is not the same. The number not assigned to a specific social class is twice as large in Sweden $(21 \%)$ as it is in England and Wales (10\%). Births assigned to the residual categories tend to represent socioeconomically marginal groups. These include single mothers and families where the father or cohabitant is unemployed or ill (only a very smal proportion are accounted for by those in the armed forces). However, groups such as single mothers may be less socioeconomically marginalised in Sweden than in England and Wales. This would be consistent with our observation that in the postneonatal period these residual groups have a lower relative risk in Sweden than in England and Wales.

\section{LEVELS OF INEQUALITY}

Although relative risks in the postneonatal period in Sweden are similar to those in England and Wales, the absolute level of inequality is substantially less. In England and Wales the difference in postneonatal risk between the manual and non-manual classes is 122 deaths per 100000 live births; between the aggregate residual category and the non-manual classes it is 458 deaths per 100000 live births. In contrast, the equivalent risk differences in Sweden are 54 and 167 deaths per 100000 live births. Nevertheless, eliminating social class differences in Sweden (if all groups had the risk of the non-manual classes) would reduce postneonatal deaths by $29 \%$. The same percentage reduction would occur if social class differences in postneonatal mortality were eliminated within England and Wales. However, if postneonatal risks in England and Wales were reduced to the level of those in non-manual classes in Sweden then nearly two thirds of postneonatal deaths would be avoided.

Risks in Swedish non-manual classes are lower than in any social class in England and Wales. In the postneonatal period these differences are substantial, with the non-manual category having almost twice the risk of its Swedish counterpart. The reasons for this substantial difference between countries is not fully understood, although it is consistent with the hypothesis that total mortality and infant mortality in a country are inversely related to the degree of equity in income distribution within it. ${ }^{32}{ }^{33}$ However, despite the greater equity of income distribution in Sweden than in England and Wales, we have observed similar levels of inequality in postneonatal mortality within each country. Regardless of the role of income inequity in explaining differences between countries in infant mortality it does not seem readily to explain the size of the differences within countries emphasised here.

The risks in the Swedish non-manual classes are lower than those seen in Japan, which now has the lowest level of infant mortality of any country. In 1985-7 Japanese infant mortality stood at 5.3 per 1000 live births, ${ }^{34}$ compared with 4.8 per 1000 for Swedish nonmanual classes (1985-6). The contrast is even more pronounced postneonatally where the corresponding figures for Japanese and Swedish non-manual classes were $2 \cdot 10$ and 1.46 per 1000 live births. In the absence of information on subgroups of the Japanese population with even lower risks, the rates in Swedish non-manual classes may be regarded as a new standard towards which all countries, including Sweden as a whole, should aim.

The consistent long term investment in social welfare and health care provision in Sweden over the past decades has gone alongside a substantial reduction in infant mortality. Despite this, inequalities in infant death seem to persist, particularly in the postneonatal period. We conclude that socioeconomic differences in the home environments of infants, which are likely to be important in determining levels of postneonatal mortality, ${ }^{35}$ may have been more difficult to reduce than inequities in health care.

We thank Anders Ericson, Gerry Morris, Viveca Östberg, Geoffrey Rose, and George Davey Smith for helpful comments on an early draft and Beverley Botting for providing the unpublished tabulations from the Office of Population Censuses and Surveys.

1 Wallace HM, Ericson A, Bolander AM, Vienonen M. Infant mortality in Sweden and Finland: implications for the United States. $\mathcal{f}$ Perinatology 1990;10:3-11.

2 Siölin S. Infant mortality in Sweden. In: Wallace HM, ed. Health care of mothers and Children in national health services: implication for the United States. Cambridge, Massachusetts: Ballinger, 1975:229-40.

3 Macfarlane AJ, Mugford M. Birth counts: statistics of pregnancy and childbirth. London: HMSO, 1984.

4 Diderichsen F. Health and social inequities in Sweden. Soc Sci Med 1990;31:359-67.

5 Mitchell EA. International trends in postneonatal mortality. Arch Dis Childhood 1991;65:607-9.

6 Geijerstam G. Low birth weight and perinatal mortality. Public Health Reports 1969;84:939-48.

7 Goldstein $\mathrm{H}$. Factors related to birth weight and perinatal mortality. $\mathrm{Br} \mathrm{Med}$ Bull 1981;37:259-64.

8 Guyer B, Wallach LA, Rosen SL. Birth-weight-standardized neonatal mortality rates and the prevention of low birth weight: how does Massachusetts compare with Sweden? N Engl f Med 1982;306:1230-3.

9 Powell-Griner E, Woolbright A, Trends in infant deaths from congenital anomalies: results from England and Wales, Scotland, Sweden and the United States. Int $\mathcal{F}$ Epidemiol 1990;19:391-8.

10 Wallace HM. Health care of mothers and children in national health services: implications for the United States. Cambridge, Massachusetts: Ballinger, 1975

11 Holstein BE. Denmark country paper. Recent review of empirical studies. In: Kohler L, Martin J, eds. Inequalities in health and health care. Report of an

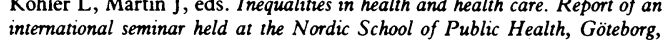
intermational seminar held at the Nordic School of Public Health, Göteborg,
Sweden. Fanuary 1985. Göteborg: Nordic School of Public Health, 1985:45Sweden. Fanuary 1985. Göte
68. (NHV-Report 1985:5.)

12 Valkonen T. Social inequality in the face of death. In: European Population Conference 1987: issues and prospects. Plenaries. Helsinki: IUSSP/Central Statistical Office of Finland, 1987:201-61.

13 Whitehead M. Inequalities in health. The health divide. Harmondsworth: Penguin, 1990.

14 Ericson A, Eriksson M, Westerholm P, Zetterström R. Pregnancy outcome and social indicators in Sweden. Acta Paediatr Scand 1984;73:69-74.

15 Ericson A, Eriksson M, Zetterström R. The incidence of congenital malformations in various socioeconomic groups in Sweden. Acta Paediatr Scand 1984;73:664-6.

16 Ericson A, Eriksson M, Källen B, Zetterström R. Maternal occupation and delivery outcome: a study using central registry data. Acta Paediatr Scand 1987;76:512-8.

17 Ericson $A$, Eriksson $M$, Källen $B$, Zetterström R. Socio-economic variables and pregnancy outcome. 1. Birthweight in singletons. Acta Paediatr Scand 1989;360(suppl):48-55.

18 Ericson $A$, Eriksson $M$, Källen $B$, Zetterström $R$. Socio-economic variables and pregnancy outcome. 2. Infant and child survival. Acta Paediatr Scand 1990;79:1009-16.

19 Townsend P, Davidson N. Inequalities in health. The Black report. Harmondsworth: Penguin, 1990

20 Cnattingius S, Ericson A, Gunnarskog J, Källen B. A quality study of a medical birth register. Scand f Soc Med 1990;18:143-8. 
21 Vågerö $\mathrm{D}$, Lundberg $\mathrm{O}$. Health inequalities in Britain and Sweden. Lancet 1989;ii:35-6.

22 Lundberg O. Class and health: comparing Britain and Sweden. Soc Sci Med 1986;23:511-7.

23 Olausson PO, Vågerö D. A Swedish classification into social classes based on census information and comparable to the British classification - a proposal. census information and comparable to the Brit

24 Office of Population Censuses and Surveys. Classification of occupations, 1980. London: HMSO, 1980

25 Adelstein AM, Macdonald Davies I, Weatherall JAC. Perinatal and infant mortality: social and biological factors 1975-77. London: HMSO, 1980. (Studies in Medical and Population Subjects No 41.)

26 Breslow NE, Day NE. Statistical methods in cancer research. Vol 2. The design and analysis of cohort studies. Lyons: International Agency for Research on Cancer, 1987. (IARC scientific publications No 82.)

27 Greenland S. Variance estimators for attributable fraction estimates consistent -in both large strata and sparse data. Statist Med 1987;6:701-8.

28 Rietz E. Sterblichkeit und Todesursachen in den Kindenjahren. Acta Paediatr Scand 1930;9:(Suppl III)
29 Quine S. Problems in comparing findings on social class cross-culturallyapplied to infant mortality (Australia and Britain). Soc Sci Med 1990;30: 1283-8.

30 Illsley R. Comparative review of sources, methodology and knowledge. Soc Sci Med 1990;31:229-36.

31 Szreter SRS. The genesis of the Registrar-General's social classification of occupations. British fournal of Sociology 1984;35:522-46.

32 Wilkinson RG. Income distribution and life expectancy. Br Med f 1992;304: 165-8.

33 Wennemo I. Infant mortality and inequality. A comparison of 18 industrialized countries. Stockholm: Department of Sociology, Stockholm University,

34 Nakamura $Y$, Nagai $M$, Yanagawa $H$. A characteristic change in infan mortality rate decrease in Japan. Public Health 1991;105:145-51.

35 Pharoah POD, Morris JN. Postneonatal mortality. Epidemiol Rev 1979;1 $170-83$.

(Accepted 7 fuly 1992)

\section{How safe is Scottish hot air?}

\section{Alastair M Thompson}

Department of Surgery, Raigmore Hospital, Inverness IV2 3UJ Alastair M Thompson, surgical registrar

Correspondence to: Department of Surgery, Royal Infirmary, Edinburgh EH3 9YW.

$B M \mathcal{F}$ 1992;305:691
Modern hot air balloons consist of a gondola, containing the pilot, passengers, and propane fuel tanks, suspended beneath a powerful gas burner that intermittently heats air within a nylon canopy overhead. Since the first flight by a British aeronaut (a former Edinburgh medical student) in 1784 ballooning accidents have continued to make front page news. ${ }^{1}$ However, the accurate documentation of ballooning injuries remains sparse. ${ }^{23}$ Theoretical risks include thermal burns from propane; trauma on falling from the gondola (particularly on take off or landing); hypoxia; and unintentional contact with trees, buildings or overhead electricity wires. This paper records a prospective study of injuries to balloonists based in Scotland to find improvements for safer flying.

\section{Methods and results}

Over an eight year period (1983 to 1991) accidents were documented from the 10 pilots, $100 \mathrm{crew}$, and 15 hot air balloons based annually in Scotland. Minor injuries (such as abrasions, small haematomas, or facial hair loss) are commonplace ${ }^{3}$ and were excluded.

Twelve people were seriously injured on nine flights over the eight years and estimated 2000 hours of flying time (table). Limb and facial injuries were most common. Eight of the injured required hospital treatment, nine were unable to return to work immediately, but all 12 made an eventual recovery and eight flew again.

Eight subjects were injured on landing, and two of the aircraft were destroyed. Six cases $(1,2,3,7,11$, and 12) occurred on landing in mountainous terrain and (like case 10) involved the emergency services. Cases 5 and 6 necessitated enforced landings. All the pilots had less that 500 hours of flying experience, and seven of the nine accidents involved private pilots rather than commercial pilots. In five accidents pilot error and changing weather conditions were considered the major causes of the accident. There were no thermal injuries from the propane fuel.

\section{Comment}

Control over a hot air balloon in flight is limited, with the aircraft prey to the vagaries of the weather. Until recently modern ballooning injuries were poorly documented ${ }^{2}{ }^{3}$ and often sensationalised by the media. Six different Scottish hospitals have treated ballooning injuries in the past decade. The casualties in case 2 (subject multiply injured, rescued unconscious from open water) and case 10 (subject grasped $220 \mathrm{kV}$ overhead power wires) clearly benefited from rapid evacuation and hospital attention. The majority of other injuries were to the limbs, sometimes involving considerable force (case 1), and face. Injuries to the face were due to spectacles (which should be removed before landing) or failure to wear crash helmets. It is notable that most accidents occurred during landing. Flights over mountainous territory should not be undertaken lightly (and accounted for half of the casualties), given the unpredictable weather conditions over often hostile landing terrain. The two young crew who experienced vasovagal attacks on unrelated flights were laid prone in the gondola until they recovered. Neither flight went over 2500 feet above mean sea level and the pilot and other crew remained well; thus hypoxia is unlikely to have contributed to their collapse. $^{2}$

The hot air balloons cited in this series were up to 90000 cubic feet $\left(2550 \mathrm{~m}^{3}\right.$; up to five persons) in size. These are smaller than most commercial passenger carrying balloons, the pilots of which are required to pass regular flight tests, although accidents still occur. ${ }^{45}$ Three private pilots accounted for nine of the 12 cases in this series. Thus potential aeronauts should choose a commercial pilot with a good safety record flying a balloon certified for passenger carrying by the Civil Aviation Authority, wear appropriate safety equipment, and fly in good weather.

1 Balloon crashes. Observer 1992 Jan 12:1.

2 Harding RM, Mills FT. Special forms of flight I: balloons, gliders and hang gliders, $B M \mathcal{F}$ 1983;287:277.

3 Thompson AM. Aviation medicine: balloons. BMf 1983;287:614.

4 Accident incident summary: balloons. Flight Safety Bulletin 1991;27(3):44.

5 Accident incident summary: balloons. Flight Safety Bulletin 1991;27(4):44-

(Accepted 30 fuly 1992)

\begin{tabular}{|c|c|c|c|c|c|c|c|c|c|}
\hline $\begin{array}{l}\text { Case } \\
\text { No }\end{array}$ & $\begin{array}{l}\text { Age range } \\
\text { and sex }\end{array}$ & Injuries & $\begin{array}{c}\text { Hospital } \\
\text { treatment }\end{array}$ & Surgery & $\begin{array}{c}\text { Time off } \\
\text { work }\end{array}$ & Role & $\begin{array}{c}\text { Pilot's } \\
\text { capacity* }\end{array}$ & Phase of flight & Comments \\
\hline 1 & $20-30 M$ & Dislocated elbow, facial lacerations & Yes & Yes & Yes & Pilot ] & & & \\
\hline 2 & $10-20 \mathrm{~F}$ & Fractured ribs, head injury, facial bruising & Yes & No & No & Crew & PPL & Landing. Balloon destroyed & Pilot error in adverse weather: air-sea rescue ( 1 other unhurt) \\
\hline 3 & $10-20 \mathrm{M}$ & Knee haematoma & No & & No & Crew & & & \\
\hline 4 & $50-60 \mathrm{M}$ & Fractured ankle & Yes & No & Yes & Pilot & PPL & Landing & Pliot error \\
\hline 5 & $10-20 \mathrm{M}$ & Vasovagal attack & No & & No & Crew & PPL & Mid-flight & Landed immediately \\
\hline 6 & $10-20 \mathrm{~F}$ & Vasovagal attack & No & & No & Crew & PPL & Mid-flight & Landed immediately \\
\hline 7 & $50-60 \mathrm{~F}$ & Thigh haematoma, facial lacerations & Yes & No & Yes & Passenger & CPL & Landing & Adverse weather. Helicopter rescue ( 2 others unhurt) \\
\hline 8 & $30-40 \mathrm{~F}$ & Facial lacerations and haematoma & No & & Yes & Passenger & CPL & Landing & Passenger disobeyed pilot's landing briefing \\
\hline 9 & $10-20 \mathrm{M}$ & Fractured tibia and fibula & Yes & Yes & Yes & Ground crew & PPL & Mid-flight & Tripped chasing balloon \\
\hline 10 & $30-40 \mathrm{~F}$ & Electrical burns on hands and wrists & Yes & Yes & Yes & Crew & PPL & Take off & Pilot error - flew into power wires ( 2 others unhurt) \\
\hline il & $30-40 \mathrm{M}$ & Thigh haematomas, laceration & Yes & No & Yes & Pilot $\}$ & PPL & Landing. Balloon gondola destroyed & Pilot error in adverse weather \\
\hline 12 & $20-30 \mathrm{M}$ & Severe back muscle spasm (unable to walk) & Yes & No & Yes & & & & \\
\hline
\end{tabular}

